\title{
Linguagem e conhecimento por imagens:
}

\section{Conversações entre Benjamin, Bakhtin e Pasolini} Language and knowledge through images: Conversations between Benjamin, Bakhtin and Pasolini

\section{Por Danilo Marques da Silva Godinho e Cíntia de Sousa Carvalho}

\author{
Introdução
}

O artigo em questão visa produzir uma reflexão acerca do lugar da linguagem na produção do conhecimento, mais especificamente da linguagem das imagens técnicas. Assim, busca compreender teoricamente de que modo o universo cinematográfico pode oferecer subsídios para uma produção acadêmica por meio de imagens.

Parte-se do pressuposto que a utilização da imagem técnica na pesquisa possibilita que se instaure uma relação de outra densidade no encontro entre o eu e o outro, que se desdobra, em última instância, em uma produção de conhecimento completamente afetada pelo aparato técnico. Deste modo, pretendemos compreender em que medida a pesquisa em ciências humanas pode se beneficiar de outros recursos metodológicos - no caso, a videogravação - para possibilitar uma produção de conhecimento mais encarnada, que, além do texto escrito, aposte também na criação de narrativas imagéticas.

Para dar concretude aos objetivos listados, veremos em que medida o pensamento de Walter Benjamin (1892-1940) e Mikhail Bakhtin (1895-1975) acerca da linguagem pode nos auxiliar na análise da produção teórica e cinematográfica de Pier Paolo Pasolini, de modo que possamos pensar uma escrita acadêmica por imagens. A obra deste último é utilizada como mote que nos auxilia a responder as inquietações anteriormente apresentadas, visto que Pasolini esteve presente nos dois universos que nos interessam particularmente, o da produção teórica e o do cinema. 
Portanto, as reflexões deste autor nos ajudam a compreender de que modo a pesquisa acadêmica pode se beneficiar da produção imagética.

De saída, delinearemos com qual definição de imagem técnica estamos afiliados. Neste caso, contaremos com o auxílio do entendimento proposto por Vilém Flusser (1920-1991) a partir da leitura que faz do legado teórico deixado por Walter Benjamin. Os autores nos apontam a importância de não naturalizarmos as imagens técnicas, lembrando-nos de que são produtos culturais, estando, portanto, a serviço de maneiras de ver, sentir e interpretar a realidade, mediando com isso o modo como experimentamos o mundo.

O estudo de tais autores nos orienta na reflexão acerca da importância de analisarmos com mais cuidado as apropriações irrefletidas das imagens técnicas, hábito comum em nossa sociedade. Tomadas como prontas ou acabadas, as imagens nos capturam seduzindo-nos a um perigoso apassivamento. Ficamos então sujeitos à superfície de sua condição, sem atentarmos para a série de signos/conceitos que guardam em suas camadas mais profundas. Dessa forma, à contramão de uma perigosa alienação a que frequentemente nos submetemos com relação às imagens técnicas, cumpre problematizarmos a sua apropriação pelo ser humano de modo a não permitir que passem a dominar as nossas vontades e desejos de maneira irrefletida.

É especialmente interessante que esta reflexão se dê a partir de uma incorporação das imagens técnicas, de seu uso e problematização nos domínios da pesquisa acadêmica, e não a negação de seu potencial transformador. As imagens técnicas trazem consigo uma ampla e variada gama de sentidos, uma série de significados que pedem a nossa atenção. Tal fato nos incita a explorarmos o seu potencial incorporando-as na prática de pesquisa, tencionando com isso um modo de produção de conhecimento que se propõe a ser não apenas textual, mas também imagético. Vejamos, então, de que modo o diálogo entre Benjamin, Bakhtin e Pasolini nos oferece elementos para refletirmos acerca desta discussão.

\section{Metafísica da linguagem em Walter Benjamin: um olhar sobre a ontologia das imagens técnicas}

Faz-se necessário aqui discorrer sobre a concepção de Benjamin (1992) acerca da linguagem. Tais reflexões são bem-vindas na medida em que o autor, ao trazer a dimensão metafísica da linguagem, tece também uma crítica à alienação do homem e à cisão entre a vida e 

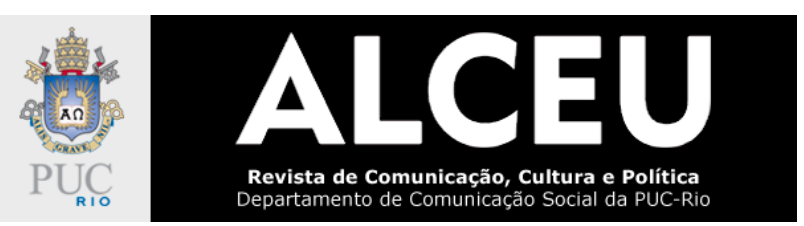

a cultura. É neste sentido que pensarmos a linguagem em Benjamin nos auxilia a rever o lugar das ciências humanas, ao indagar se estas potencializam a cisão entre a palavra e a coisa - a partir do modo como produzem conhecimento -, ou se possibilitam a aproximação entre essas dimensões.

Ao analisar os modos como a linguagem é apropriada e se configura nas relações entre os sujeitos, Benjamin (1992) percebe que há uma verdadeira esquizofrenia entre o discurso e a vida, tão presente no formalismo linguístico de sua época, que considerava a linguagem apenas em sua parcialidade comunicadora. Para tecer uma crítica a esse utilitarismo linguístico, o autor, em vez de se opor à linguagem na concepção de que esta apenas encarcera a vida, acredita que seja por meio dela e nela que há a capacidade de revertermos o formalismo linguístico que esvaziou nossa experiência.

Para sustentar sua aposta, Benjamin recorre à origem da constituição da linguagem, a fim de desnaturalizar este lugar monolítico ocupado por ela nos dias atuais. Com esse movimento, o autor visibiliza o processo que fez com que a linguagem fosse tomada apenas como instrumento, para que possamos nela mesma encontrar subterfúgios a esta engrenagem de opressão linguística. Benjamin (1992) utiliza-se da metáfora bíblica para expressar tal reflexão, como veremos a seguir.

A linguagem no início dos tempos não era utilizada para o diálogo entre os homens. Muito mais do que um instrumento de comunicabilidade, a linguagem pura era absoluta, expressava a própria coisa em sua essência e existia independentemente dos seres humanos. O nome, portanto, tinha o potencial de dar conta da essência total da coisa e criá-la, nomeá-la (linguagem adâmica).

Com a queda do paraíso imputada pelo pecado original, a linguagem perdera sua força totalizadora, e o verbo tornou-se propriamente humano, ou seja, o homem ficou então condenado a dar sempre sentido às coisas por meio da linguagem. É nessa cisão entre as palavras e as coisas que a linguagem sofreu uma mutação, pois a língua sagrada passou a ser profana, ou seja, limitada a apenas comunicar. Dessa forma, a palavra não expressa, apenas comunica algo exterior a ela própria (BENJAMIN, 1992).

Para fugir do círculo vicioso da instrumentalização da linguagem e dos sujeitos, Benjamin nos impele a pensar em modos de subverter essa lógica, na possibilidade de recuperação de uma essência perdida da linguagem. É o resgate dessa essência que poderá possibilitar que o homem se torne livre novamente e não perpetue o cárcere da incessante produção de sentidos sobre a vida por meio da linguagem instrumentalizada. Como modo de implodir com o utilitarismo linguístico 

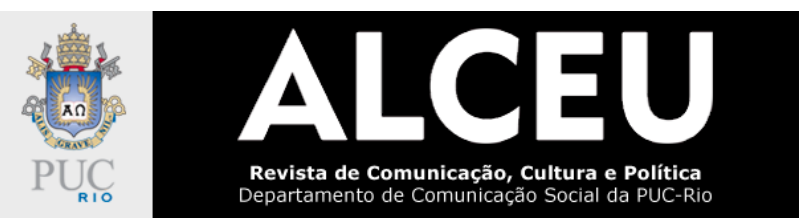

e potencializar a capacidade nomeadora da linguagem, Benjamin perscruta, nas camadas mais profundas de sentidos, as semelhanças extrassensíveis (BENJAMIN, 1992).

O convite de Benjamin por meio da metáfora da linguagem seria um retorno a essa energia mimética perdida, como possibilidade de entrar em contato com o sentido mais profundo das próprias coisas. Percebemos que mesmo que o autor mapeie a existência de um viés utilitarista da linguagem, ele a percebe também como potência capaz de subverter a lógica pragmática. Apesar do divórcio da palavra e da coisa, recuperar a pura expressão, algo que se encontra adormecido na linguagem, é modo de se afastar do utilitarismo linguístico e de suas limitações de semântica que serão sempre parciais quando se busca dar um sentido à vida.

Devemos ter em consideração que, se com a queda do paraíso recebemos o castigo de ter que oferecer sempre um sentido às coisas, esse sentido será sempre precário. Por outro lado, tal como Benjamin nos lega, é na própria linguagem que podemos subverter essa limitação, se nos distanciarmos dos sentidos canonizados e possibilitarmos que a própria vida narre como se processa. Portanto, podemos subverter essa lógica ao proporcionarmos que o conhecimento acadêmico se reinvente por meio de imagens técnicas, sem que com isso percamos a precisão e o rigor científicos.

Mas, dentro deste contexto de discussão, o que seriam, afinal, as imagens técnicas? Em que se diferenciam dos demais tipos de imagens a ponto de terem condições de enriquecerem a produção do conhecimento desde uma perspectiva diversa?

Filósofo reconhecido como pensador dos novos media, e herdeiro direto da linhagem de pensamento de Walter Benjamin, Flusser (2008) cunhou o termo escalada da abstração para designar em que ponto a reprodutibilidade de imagens técnicas atinge em cheio o cotidiano sociocultural no contexto da pós-modernidade. Segundo o autor, a produção vertiginosa de imagens programadas por aparelhos inaugurou uma relação de outra ordem com o mundo, na qual as linhas escritas em planos dão lugar a pontos imaginados sob a forma de cenas.

Contrapondo as imagens técnicas ou tecno-imagens às imagens tradicionais, Flusser (2008) recorre à química e à física para demonstrar o quanto tais imagens divergem do ponto de vista ontológico: enquanto as imagens tradicionais são produzidas a partir de volumes, isto é, abstrações feitas a partir de matérias, as imagens técnicas são superfícies planas produzidas a partir de pontos, feixes de fótons e elétrons que se juntam fazendo com que as abstrações sejam concretizadas em imagens. 


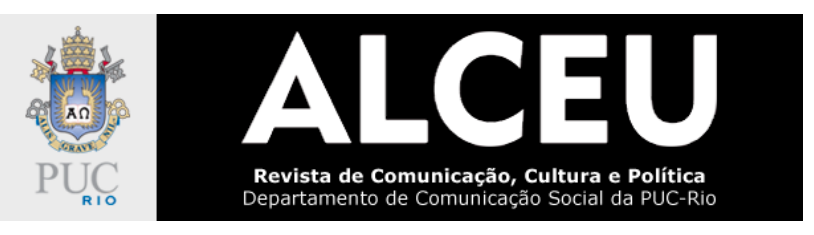

É a partir deste esquema reflexivo que Flusser (2008) convoca a necessária conscientização crítica com relação ao comportamento mágico por nós assumido, comportamento este disseminado pelo fascínio que as imagens técnicas exercem no mundo contemporâneo. $O$ efeito da presença cada vez mais intensa destes aparelhos em nosso cotidiano leva o autor a observar uma nova forma de existência, mais etérea e menos material, mais mental e menos corporal, ficando concentrada na "ponta dos dedos" tanto dos imaginadores quanto dos usuários das mídias imagéticas.

Neste sentido, o autor chama a atenção para "a emergência de um nível de consciência novo", no qual nossos hábitos e valores cotidianos têm se organizado em torno das imagens técnicas, muito embora haja de nossa parte um desinteresse completo pelos processos a partir dos quais as imagens são formadas, o que implica profundas mudanças no campo das nossas vivências. É isto que Flusser (2008) chama de "utopia emergente sobre a qual podemos dizer que invade a essência do nosso ambiente e de todos os nossos poros" (p.13). A essa utopia Flusser dirige sua análise crítica, ressaltando a importância de tentarmos "captar como nos movimentamos atualmente no mundo, para podermos compreender como tomamos consciência do mundo e de nós mesmos" (p.30).

Na contramão de um discurso simplista com relação ao intenso uso e presença das imagens técnicas no contemporâneo, Flusser (2008) aponta para o fato de que estas podem ser mais bem aproveitadas caso assumirmos outra posição com relação a elas, transpondo a "superfície" das suas representações para adentrar no nível "profundo" no qual toda uma semiótica se revela. As tecno-imagens são linguagem, no sentido em que são produções humanas, artefatos culturais embasados por maneiras de ver, sentir e interpretar a realidade, mediando com isso o modo como experimentamos o mundo.

Dentro desta perspectiva, as imagens técnicas não são inequívocas, dadas de antemão, apreendidas de um real que prescinde do olhar significador do homem; tais imagens são, portanto, signos responsáveis por mediar as relações entre o homem e o mundo, uma forma de linguagem.

\section{Bakhtin: Linguagem e produção de conhecimento nas ciências humanas}

Ainda refletindo sobre a linguagem, à mão dos argumentos presentes em Flusser e Benjamin, Mikhail Bakhtin nos lega uma instigante reflexão acerca do seu caráter decisivo enquanto 


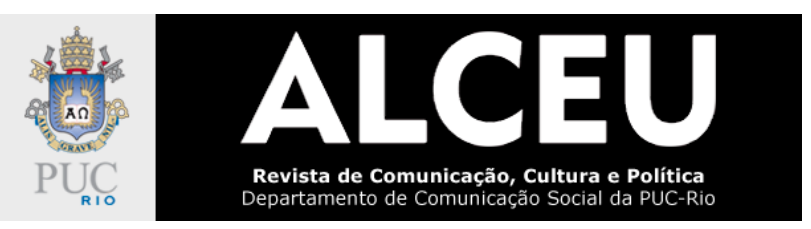

atividade crítica capaz de desestabilizar os paradigmas de verdade presentes no âmbito da produção do conhecimento em ciências humanas. A crítica de Bakhtin (1992) recai sob os modos de produção de conhecimento no interior das ciências humanas, que buscam a todo custo incorporar os paradigmas de verdade usados no âmbito das ciências da natureza, desconsiderando com isso a especificidade de seu campo epistêmico, especificidade esta que provém do fato de ser o próprio homem o seu objeto de análise.

As ciências humanas não se referem a um objeto mudo ou a um fenômeno natural, referem-se ao homem em sua especificidade. O homem tem a especificidade de expressar-se sempre (falar), ou seja, de criar um texto (ainda que potencial). Quando o homem é estudado fora do texto e independentemente do texto, já não se trata de ciências humanas (mas de anatomia, de fisiologia humana, etc.) (BAKHTIN, 1992, p. 334).

Neste sentido, a discussão proposta por Bakhtin visa tensionar as questões que se colocam quando a ênfase da produção de conhecimento recai sob o próprio homem, objeto que tem por excelência uma indeterminação inerente. Isso aponta para a impossibilidade de se adotar universais em teorias que pretendam dar conta de modo absoluto dos atos praticados na vida, pois estes acontecem de maneira imprevisível.

O que aprendemos, ao adentrar o complexo pensamento de Bakhtin, é que a vida extrapola os juízos que arrogam para si um estatuto de verdade último universalmente válido. Como sempre vai haver a busca pelo conhecimento, pode-se dizer que somos seres em eterno estado de inacabamento, sempre dispostos a estabelecer mais e mais vínculos uns com os outros e com a natureza como um todo. Se, portanto, a vida é infinita e aberta por constituição, como pode a linguagem apreendê-la e transformá-la em conhecimento passível de ser transmitido?

De acordo com Bakhtin (1992), a atividade estética (cultura) e a vida são dois campos distintos que não se misturam, mas que guardam relações importantes um com o outro. Ou seja, o mundo da vida é o aqui e agora da vivência, já o mundo da cultura é a tentativa de retratar o ato de viver, enformando-o sob a forma de um objeto. Neste sentido, o autor pondera os limites do mundo da cultura na sua pretensão em apreender de todo o mundo da vida, visto que este está sempre em permanente devir, sendo, portanto, inapreensível de todo. Deste modo, Bakhtin considera que a produção de sentidos sobre a vida, feita por meio da produção estética - seja pela via da arte ou da ciência - é um projeto que necessariamente estará sempre inacabado, tal como inacabado permanece o homem desde o nascimento até o momento de sua morte. 


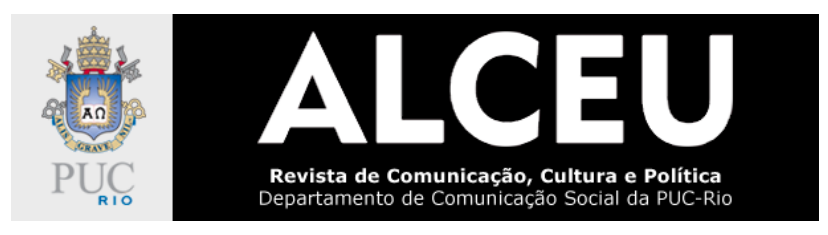

Entretanto, Bakhtin considera que essa cisão entre mundo da cultura e mundo da vida pode ser reparada pela responsabilidade a partir da qual cada um assume o lugar único e intransferível que ocupa no mundo. $O$ ato singular e irrepetível praticado no aqui e agora de uma existência é o que transforma o conteúdo experimentado em uma atividade estética inteiramente original (BAKHTIN, 1992).

O que garante o nexo interno entre os elementos do indivíduo? Só a unidade da responsabilidade. Pelo que vivenciei e compreendi na arte, devo responder com a minha vida para que todo o vivenciado e compreendido nela não permaneçam inativos. (...) Arte e vida não são a mesma coisa, mas devem tornar-se algo singular em mim, na unidade da minha responsabilidade. (BAKHTIN, 1992, p. XXXIII).

De acordo com o autor, a responsabilidade do ato de cada um reside na singularidade com que é praticado, pois nenhum ato é repetível, o que faz com que cada gesto traga consigo todo um potencial criativo. A seguir, veremos de que modo essa discussão acerca da linguagem e da atividade estética proposta por Benjamin e Bakhtin atravessa as reflexões presentes na obra de Pasolini.

\section{Pasolini: $O$ cinema como língua escrita da realidade}

Refletiremos neste tópico de que modo Pasolini, em sua obra, buscou engrossar os fios que regeneram a intimidade perdida entre experiência vivida na realidade e o que se produz sobre essa experiência, seja por meio da linguagem escrita, seja pela produção imagética. Pier Paolo Pasolini (1922-1975) nasceu em Bolonha, foi poeta, editor, pintor, semiólogo, ensaísta, crítico literário, crítico cinematográfico, jornalista e cineasta. Dedicou sua obra a tecer críticas aos regimes totalitários, ao fascismo do consumo, à homogeneização dos prazeres, do desejo e da felicidade, e toda forma de opressão que se apresentava na Itália naquele momento histórico (SILVA, 2007).

A primeira instigante consideração acerca da obra de Pasolini refere-se à maneira como o autor se relacionava com o mundo dos homens e das coisas. Para Pasolini, os objetos do mundo não são mudos; antes, possuem uma linguagem, uma comunicabilidade pedagógica e evocam sentidos (PASOLINI, 1990). Já no que se refere aos seres humanos, Pasolini não trabalhava com concepções abstratas. Pelo contrário, o autor, ao diagnosticar uma realidade por ele observada, preocupou-se em situar os sujeitos de fala, contextualizá-los, encarná-los em uma vivência e em uma cultura. 
Se procuro 'descrever' o aspecto terrível de uma nova geração inteira, que sofreu todos os desequilíbrios devidos a um atroz e estúpido desenvolvimento, e procuro 'descrevê-lo' neste jovem, neste operário, não sou certamente compreendido. Porque ao sociólogo e ao político profissionais não importa pessoalmente nada deste jovem, deste operário. Ao contrário, a mim pessoalmente é a única coisa que importa (LAHUD apud PASOLINI, 1990, p. 11).

Pasolini apresentou em sua trajetória uma inquietação que se assemelha ao que nos impulsiona à reflexão posta neste artigo. O autor iniciou sua obra produzindo textos, ensaios e poemas: portanto, valendo-se da língua escrita para exprimir suas reflexões e críticas. Entretanto, verificou que a língua falada e escrita por si só estava enfraquecida, pois apenas evocava a realidade, mas não a apresentava de fato. Além disso, a língua naquele momento histórico estava tiranizada pela cultura fascista, que a utilizava para impor um regime de valores. Atento a essas questões, Pasolini começou a defender a utilização do friulano na produção literária, em detrimento da língua oficial italiana, dialeto falado por camponeses que, de acordo com o autor, estava em extinção na Itália. A opção por esse tipo de escrita, uma opção quase benjaminiana, era a crença de que, nessa língua campesina, residia a única liberdade possível naquele momento, esquivandose com isso do controle do Estado (SILVA, 2007).

Ainda à mão dos argumentos acima, Pasolini diagnostica que há uma crescente instrumentalização da linguagem pela cultura, que ao esvaziá-la de sentido, torna-a sem implicação com a vida, inexpressiva, e, portanto, apolítica. Essa crítica se vincula à cisão entre vida e cultura apresentada anteriormente por Bakhtin e à noção de empobrecimento linguístico proposta por Benjamin. Vejamos, então, como Pasolini parece indiretamente responder às preocupações destes dois autores.

Apaixonado pela realidade, Pasolini se ressentia da distância criada entre a produção escrita sobre a vida e a própria vida e, buscou então, entender de que modo essa apatia da linguagem poderia ser subvertida. Deste modo, vislumbrou produzir um objeto estético que não fosse ferramenta de evocação da realidade, mas que a mostrasse, apresentando-a sem atalhos, para que assim pudesse efetivamente concretizar de modo mais direto suas denúncias sobre as injustiças que lhe cercavam. Neste sentido, Pasolini apostou no recurso cinematográfico, pois este se constituiu como passaporte para a resolução do impasse. Passou a compreender, então, que a linguagem cinematográfica é a língua escrita da realidade, que resolve a uniformização da linguagem inexpressiva ao mostrar a realidade por meio da própria realidade (LAHUD, 1993). 


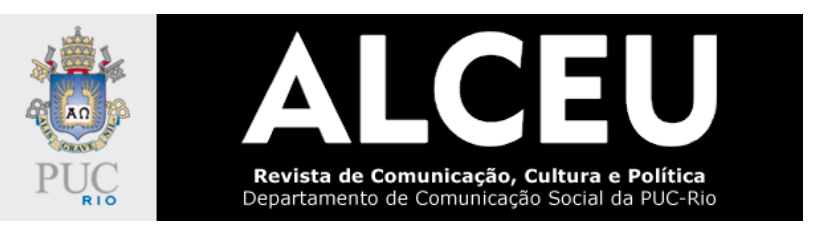

Dentro deste contexto, Pasolini questionou a teoria cinematográfica até então vigente, se afiliando ao neorealismo italiano, um dos principais movimentos de vanguarda artística ocorrido no início da segunda metade do século XX. O neorealismo italiano tinha como premissa básica mostrar a realidade tal como vivida pelas classes populares no contexto da Europa do pós-guerra. Os filmes produzidos dentro dessa proposta tinham o compromisso político de dar a ver ao espectador que a realidade é por si mesma uma produção humana, sendo, por isso mesmo, necessariamente linguagem. Pasolini contribuiu nessa seara enxergando no cinema a possibilidade de apresentação da realidade tal como ela é, ou seja, esteve ao longo de sua carreira de diretor inteiramente comprometido com um uso da linguagem do cinema como forma de se aproximar mais da realidade, tendo como base o que considerou semiologia da realidade (SILVA, 2007).

Devemos esclarecer, deste modo, o que Pasolini considera como Realidade. Para o autor, esta é a única linguagem que poderia ser considerada como Linguagem verdadeiramente, visto que todas as outras seriam apenas recodificações dessa linguagem primeira (e primitiva). Os signos verbais, portanto, seriam a tradução dos signos não verbais, ou seja, as línguas (escrita e falada) apenas traduziriam os signos da Linguagem da Realidade. É nesta esteira que Pasolini busca retraduzir a realidade de modo mais fiel, apostando na potência expressiva do cinema que apresenta a linguagem viva das coisas. Ora, se o cinema re-produz de modo mais fidedigno a realidade, então esta é em si mesma um cinema em estado de natureza, o real como cinema in natura. Deste modo, a realidade, para o autor, já é em si um signo, a expressão pura de si (LAHUD, 1993), expressão da qual as diversas formas de representação, tais como a literária e a pictórica, por exemplo, tentam se aproximar, visando representá-la; o cinema, portanto, seria, de acordo com Pasolini, não um modo de representar a realidade, mas sim de a apresentar. A produção cinematográfica surge como a única ferramenta de apreensão da realidade que não precisa dissimulá-la, potência capaz de fazer falar de modo direto as próprias coisas do mundo.

O cinema, ao contrário desses outros meios expressivos, também não representa a realidade, uma vez que não constitui em si um meio, um instrumento do qual o sujeito apresenta aos espectadores o mundo externo e preexistente. O cinema "re-produz" a realidade: imagem e som, ou seja, ele a produz novamente, o espaço, o tempo, as relações; e para fazê-lo se serve da mesma realidade material e física: dos corpos, dos gestos, dos objetos e inclusive da temporalidade que pretende reproduzir. À diferença dos outros modos de expressão, que ao retraduzirem o mundo distanciamse da linguagem das ações e de seu código original, o cinema tem a peculariedade de reproduzi-lo fielmente. O cinema permite assim estar dentro da realidade sem nunca sair dela: permitindo expressá-la por meio dela própria os seus aspectos mais ocultos, sua dimensão "sagrada", não naturalizada (SILVA, 2007, p. 32). 


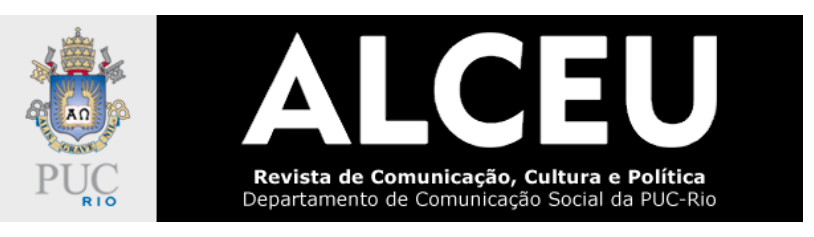

Importante ressaltar que o cinema para Pasolini, mais do que instrumento de acesso direto, por excelência, à realidade, é uma língua, sendo então, um sistema de signos da realidade (SILVA, 2007). Ainda sobre esta questão, Pasolini se questiona: se o cinema é a língua escrita da realidade, deve, portanto, se aproximar da realidade pelo meio mais próximo de sua lógica temporal, como, por exemplo, no plano-sequência infinito? Ora, se o cinema possibilita a reaproximação entre mundo da vida e mundo da cultura, tal como aponta Bakhtin, o melhor modo de desestabilizar esse divórcio não seria reproduzir a vida tal como ela é, ou seja, lançando mão de filmagens sem cortes e edição?

Pasolini considera que o cinema aproxima-se mais da realidade não quando a apresenta em plano-sequência a fim de imitar a temporalidade da vida real, pois o tempo enquanto continuidade é para o diretor uma ilusão; pelo contrário, avalia como mais fidedigno o cinema que trabalha com vários cortes, editando e apresentando diferentes planos, pois parte do pressuposto de que na vida estamos o tempo todo operando uma seleção daquilo que queremos colocar em destaque, ou seja, nosso olhar é necessariamente enviesado, editando e montando as cenas, sem que tenhamos noção da totalidade do que está acontecendo à nossa volta. Com isso, Pasolini desmistifica o paraíso da não-edição, argumentando que este não existe nem mesmo na vida.

Há que percebermos, porém, que Pasolini, ao falar de montagem e edição, refere-se a um momento particular do cinema, qual seja, à produção de um filme. Neste ponto, devemos compreender que para o autor há uma diferença entre o cinema (linguagem) e o filme (produto desta linguagem), pois, se o primeiro corresponde diretamente à vida, no caso do segundo essa coincidência não se opera.

Ainda que o cinema seja uma Linguagem da Realidade por excelência, que a pode captar na sua expressividade mais pura, o filme, por sua vez, seria um recorte possível para a vida a partir da montagem. O filme seria a síntese que detém o fluxo ininterrupto do tempo para oferecer uma objetivação moral dos fatos e das relações, ou seja, um sentido ao todo. Em outras palavras, quando se edita, opera-se concomitantemente um processo de morte e nascimento: mata-se a possibilidade do plano-sequência, excluindo-se muitas imagens, mas dá berço a uma leitura e sentido sobre a vida, o próprio filme. O desafio seria, portanto, não fugir da edição, mas possibilitar que a vida que nasce com o filme produza sentidos profundos sobre o que pretende mostrar e apresente o subjetivo de todo o material que não entrou na edição final, pois, ainda que Pasolini 
aposte no cinema, considera que os filmes nem sempre se apropriam da potência que detém o cinema (SILVA, 2007).

Em síntese, podemos considerar que Pasolini, ao se preocupar ao longo de toda sua produção em se aproximar da realidade, ofereceu uma resposta à inquietação apresentada no início deste artigo por Bakhtin. Além de encontrar uma potência no cinema para enfrentar a impenetrabilidade entre os dois mundos (vida e cultura), assumiu em sua existência de homem e diretor a responsabilidade pelos seus atos, ao compartilhar de modo encarnado o modo como enxerga o mundo do seu ponto de vista volitivo-emocional, tecendo críticas a quaisquer tentativas de naturalização e homogeneização da vida pelos regimes totalitários (LAHUD, 1993).

A preocupação de Bakhtin e de Pasolini parece-nos altamente sofisticada na medida em que consideramos que na produção acadêmica há um movimento de abstração e constante conceituação da vida, desconectado das práticas e das relações concretas. Percebemos que a busca por um rigor científico universal aprisiona as distintas ciências em modelos teóricometodológicos que, se respondem às exigências acadêmicas, tornam-se cada vez mais apartadas da vida humana. Portanto, se consideramos que o que é produzido sobre a vida (objeto estético, produção acadêmica, dentre outros) também participa ativamente da construção da própria vida, caso adotemos uma produção desencarnada, estaremos permitindo também a criação de uma vida desinteressante, esvaziada, algo já anunciado na denúncia sobre o utilitarismo linguístico feita por Benjamin.

Pasolini nos inspira a pensar em uma produção de conhecimento em que o pesquisador se encontra em um dentro sem fora (da vida) e que é, a um só tempo, afetado e ser que afeta, não conseguindo estar de modo neutro fora da realidade que teoriza. Não obstante, se as reflexões de Pasolini convidam o pesquisador a assinar de modo ativo o que produz e, se consideramos que o cinema é a língua escrita da realidade, isso requer do diretor (ou, em nosso caso, do pesquisador) a responsabilidade pelos mundos que cria com seus filmes (e pesquisas).

Em última instância, ainda inspirados pelas reflexões de Pasolini, consideramos que, assim como o diretor (pesquisador) encontra-se na vida não de modo imparcial, também o instrumental por ele utilizado - no caso em tela, a câmera - é um aparato técnico que não apenas capta a realidade, mas faz parte da própria realidade. Tal dispositivo não pode ser assumido meramente como um instrumento de registro, permanecendo nos bastidores, mas deve ser compreendido como um terceiro interlocutor que se soma aos sujeitos da pesquisa, interlocutor este que atua e 
produz sentidos no campo. Portanto, o que possibilita fazer a pesquisa, métodos e ferramentas, deve ser incluído e tornado visível. No que se refere a uma produção de conhecimento que se valha das imagens técnicas, estamos considerando a importância de dar a ver a feitura da pesquisa, além de incluir a câmera como um ator que afeta, pois ela também se encontra refletida no espelho da realidade que buscamos captar.

O compromisso ético de Pasolini com a realidade reside em ter possibilitado que sua obra fosse produzida prenhe de sentidos altamente vinculados com a vida e sua multiplicidade inacabada, em que os sujeitos expressam a singularidade de suas existências, aquilo que os faz sujeitos únicos (BAKHTIN, 1992). No próximo tópico, veremos como as contribuições teóricas sobre linguagem e cinema nos inspiraram a pensar em uma produção de conhecimento que tenha como especificidade o uso de imagens técnicas.

\section{Narrativas imagéticas na produção do conhecimento}

Nosso interesse com o presente trabalho é propor uma reflexão acerca de uma metodologia de pesquisa que seja capaz de problematizar o uso de narrativas imagéticas na pesquisa em ciências humanas. Com esse intuito, desenvolveremos, a seguir, uma discussão a respeito das implicações do uso do recurso da videogravação mediando o encontro do pesquisador com o seu outro na produção do conhecimento, tendo como inspiração a obra de Pasolini.

A aposta na prodigalidade do uso da videogravação em pesquisa acadêmica parte da premissa de que os modos de produção de conhecimento não podem estar desvinculados das práticas sociais e culturais cotidianas e, portanto, cabe ao pesquisador criar estratégias de investigação mais condizentes e integradas com a experiência do sujeito contemporâneo de ver e de ser visto a partir das mediações proporcionadas pelas imagens técnicas.

O recurso da imagem técnica desponta como forma de construir uma metodologia de pesquisa que contemple a experiência sensível, e que na forma de texto imagético acenda clarões nas cesuras do conhecimento. Justamente por ser desta ordem tal narrativa imagética perscruta o material cotidiano aprofundando-o; revestindo-o de uma compreensão que foge das análises simplistas, as imagens técnicas possuem o potencial de iluminar as contradições e as vicissitudes de uma época, contemplando-a nas suas idiossincrasias. 
Dentro dessa perspectiva, podemos pensar em uma narrativa imagética inteiramente prenhe de sentidos que revela a verdade no agora de um acontecimento compartilhado entre o pesquisador e o outro, produzindo ecos imagéticos cuja tensão por muito tempo se faça sentir. A imagem-texto funciona como registro de experiências sensíveis de mundo, que, no encontro entre pesquisador e sujeitos da pesquisa, inaugura a possibilidade de restaurar o potencial da imagem enquanto lócus privilegiado de sentidos a serem explorados por aqueles que com ela estabeleçam um diálogo.

É neste contexto de transmissão da experiência sensível vivida no encontro com o outro através da imagem técnica que defendemos um uso de tais imagens não apenas no interior do domínio acadêmico, mas também junto a uma tradição coletiva mais ampla que possa se valer dessas imagens, explorando o seu caráter de linguagem. Isso permite que as leituras sejam permanentemente re-atualizadas ao longo do tempo, transformando, com isso, o conhecimento. Portanto, trazer à tona tais imagens técnicas e confrontá-las junto à sociedade mais ampla significa elevá-las à autenticidade e legitimidade de seu devir.

As reflexões de Pasolini nos são caras, pois, ainda que busquemos ampliar o olhar para as formas de produzir conhecimento, na tentativa de garantir que a vida pulse em nossa produção acadêmica por outras vias - como a imagética, por exemplo -, não podemos perder de vista que a ciência hoje é composta necessariamente de textos escritos. Deste modo, não buscamos substituir essa narrativa pela imagética, mas pretendemos verificar quais as possibilidades existentes para, na produção acadêmica, aproximarmos vida e cultura (BAKHTIN, 1992), pois compreendemos que é possível pensar em termos de uma produção acadêmica que não se esgote no texto escrito, mas que construa narrativas de outra ordem.

Adotar esta postura implica revisar os instrumentos metodológicos que frequentemente lançamos mão no campo de pesquisa, os quais nos levam a reproduzir sempre as mesmas perguntas e receber, consequentemente, as mesmas respostas. Deste modo, partimos do pressuposto de que o campo de pesquisa (portanto, a vida) está aberto a oferecer outras respostas, mas isso também requer do pesquisador que inaugure outros modos de interpelá-lo, sendo a câmera uma potente aliada neste projeto.

Por fim, nos propomos a refletir acerca das seguintes indagações, no sentido de reinventar um modo outro de estar no campo mediado pelo uso de imagens técnicas: Por que pesquisar com imagens? Qual é a inovação/revolução que a imagem técnica traz para a produção do conhecimento? 


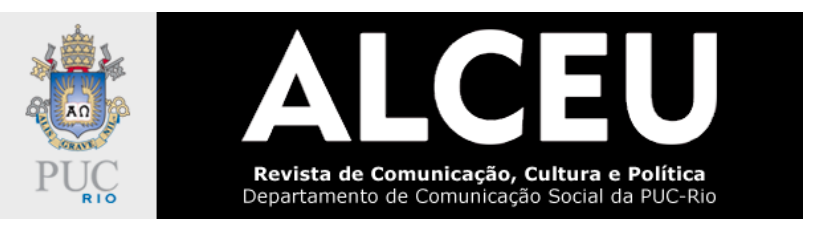

Em primeiro plano, é preciso ponderar que a utilização ou não da imagem técnica é uma decisão a ser negociada entre pesquisador e sujeitos da pesquisa, pois, sem o consentimento e envolvimento deste outro, não há conhecimento possível a ser produzido. Na pesquisa com imagens, o aparato câmera deve ser aceito como um ator que afeta a relação dos sujeitos com os pesquisadores e, portanto, o que se produz será sempre enformado pela sua presença. Além disso, há que considerarmos que existem dois aspectos centrais que devem ser levados em conta no âmbito desta discussão, quais sejam: a impossibilidade do sigilo e a eternização da imagem e do discurso.

Ainda tentando responder às perguntas acima, é preciso situar que, ao falarmos da utilização de imagens técnicas na pesquisa, não estamos nos referindo a qualquer produção de narrativa imagética. Compreendemos que o documentário é a ferramenta que nos oferece subsídios para apresentarmos a realidade por ela própria, assim como nos legou Pasolini. Diferentemente do filme de ficção, a ausência de um roteiro dado de antemão e a compreensão de que necessariamente o outro que participa da pesquisa é coprodutor do enredo apresentado, é o ponto nodal que liga universo acadêmico de pesquisa e produção documentária. Pesquisar com o outro, ancorado na técnica cinematográfica, se concretiza em sua radicalidade por meio e nesta forma de narrativa imagética específica.

No documentário há uma especificidade que diz respeito à dualidade existente entre, de um lado, estar na vida participando de uma pesquisa e, de outro, ter a consciência de que tudo o que é vivido neste enquadre está irremediavelmente sendo mediado por um dispositivo técnico que apreende e dá eternidade ao que é expressado. Portanto, é o fazer permanecer propiciado pela videogravação que implica de outro modo os sujeitos participantes, intervindo naquilo que escolhem democratizar frente à câmera. Ainda que, mesmo no documentário, os sujeitos construam personagens de si a serem atuados, havendo, portanto, uma boa dose de invenção, não há álibi frente àquilo que se diz e se mostra, pois a pessoa é convocada a responder pelo personagem que cria. O sujeito, ao participar de um documentário, não deixa de ocupar o seu lugar no mundo. Assumir este lugar singular e solitário, pois incompartilhável de todo (Bakhtin, 1992), requer assinar embaixo daquilo que é dito e apresentado.

A imagem impõe aos participantes o confronto com os seus próprios atos, possibilitando que enxerguem um excedente de visão (BAKHTIN, 1992) acerca de si mesmos, excedente este o qual não teriam acesso sem a presença da mediação técnica. Um desdobramento desta questão diz 
respeito ao fato de que, ao se assistirem, os participantes têm a oportunidade de ressignificar aquilo que viveram no momento da filmagem, intervindo na decisão da imagem final que desejam produzir. A recusa e, ao mesmo tempo, o desejo de ser filmado (situação ocorrida em muitas pesquisas realizadas por nós ${ }^{1}$ ) têm a ver com isso, visto que o personagem sabe que falar diretamente para o olhar-câmera implica acessar algo de si que não está de todo dado à sua consciência. Esse aspecto aponta ainda para o desafio de criar uma representação de si nos poucos minutos em que se está diante da câmera, o que em muitos momentos provoca temor nos participantes. Entretanto, paradoxalmente, o desejo de se apresentar e eternizar o seu quem transparece em diversos momentos no modo como se relacionam com o olhar-câmera.

Não obstante, o que por um lado é responsabilização pelo falado, por outro, é o desejo de que o falado seja a síntese perfeita do vivido. Portanto, é na edição que a responsabilidade pelo que é dito e eternizado, bem como o desejo de fazer corresponder o vivido e o dito sobre o vivido, se concretiza. Sendo assim, se a edição é um momento que diz respeito intimamente ao sujeito da pesquisa, compreendemos que ele deve ser convidado a participar, pois não concebemos o momento da montagem cinematográfica apartado do fazer da pesquisa. Na utilização de imagens técnicas, fazer pesquisa com o outro implica estar junto também no momento de morte e nascimento vivenciado pela edição (SILVA, 2007).

A proposta metodológica de se valer da mediação técnica da câmera nos moldes que ora apresentamos tem como princípio uma reflexão e problematização sobre o modo como temos nos relacionado com essa mediação no contexto contemporâneo. Neste sentido, Jobim e Souza (2008) orienta esta discussão assinalando que as transformações operadas pelas novas formas de experimentar a realidade, devido à presença cada vez mais constante das imagens técnicas em nossas vidas, exigem o reconhecimento dos códigos inscritos no âmago das relações sociais, decifrando o modo como criamos culturalmente o mundo na e pela imagem.

A autora nos mostra o quanto nos relacionamos com a mediação técnica como mero instrumento, o que aponta para um desenraizamento do homem com a história, ou, mais ainda, com a sua incapacidade de se reconhecer enquanto sujeito que participa da construção histórica (BENJAMIN, 1992). Este aspecto torna evidente o esfacelamento de nossa capacidade de narrar

\footnotetext{
1 Seguem links que apresentam parte dessa produção: https://www.youtube.com/channel/UCpu2BEiHdc4IApm3i4InApg; https://www.youtube.com/watch?v=szO57C6Hd3E.
} 


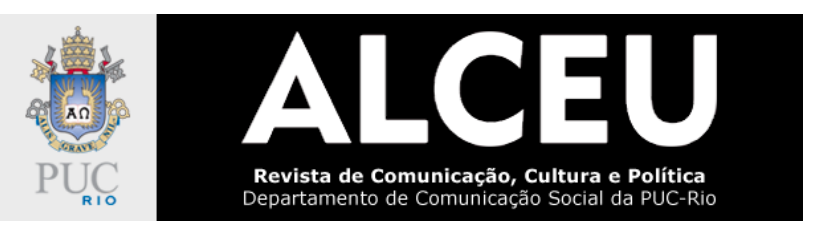

nossas impressões sensíveis de mundo, aquilo que de algum modo fica como marca ou memória do que vivemos, para compartilharmos com os outros, no âmbito da linguagem.

O olhar esvaziado do sentido narrativo, que contempla as imagens técnicas enquanto produtos naturalizados, aos quais não se deve emprestar maior importância no que concerne aos seus modos de produção e apropriação, é avesso à experiência sensível do olhar, que significa a imagem em sua peculiaridade, naquilo que a faz potência política, reflexão e problematização constante do que está sendo imaginado.

Cabe ressaltar, portanto, o imperativo de se adotar na pesquisa acadêmica, principalmente na área das ciências humanas, uma reflexão a respeito dos múltiplos modos de produção de sentido que estão por trás das imagens técnicas; ou, dito de outro modo, de toda uma estética, à qual cumpre contrapor uma ética, para que forma e conteúdo façam da experiência com as imagens uma experiência sensível em que o real é imaginado, e não capturado enquanto verdade última e absoluta. É neste sentido que Jobim e Souza (2008) defende uma educação estética do olhar.

Assim como Pasolini enxergou no cinema a possibilidade de erigir uma crítica à cultura de sua época, apostando no potencial da imagem técnica, acreditamos que o uso de tais imagens em pesquisa acadêmica é promissor no sentido de criar as condições para que o conhecimento se propague para além do domínio acadêmico. Trata-se, com isso, da luta em prol de uma educação estética do olhar capaz de restituir o potencial re-criativo ao sujeito contemporâneo.

\section{Considerações finais}

Se com Benjamin (1992) entendemos que vivemos um esvaziamento da linguagem e com Bakhtin (1992) aprendemos que o objeto das ciências humanas é por excelência o ser expressivo e falante, à mão de Pasolini compreendemos que a imagem técnica pode ser um recurso que vivifica a linguagem, ampliando-a por meio das imagens técnicas. No campo de pesquisa atravessado pelo aparato técnico da videogravação, o participante passa a ser capaz de dizer de si e do mundo não apenas a partir do seu discurso, tornado escrito, mas também da pantomina comunicada pelo seu corpo, e reproduzida pela imagem técnica, abrindo novas possibilidades de pensarmos a potência linguística.

Além disso, o documentário ocupa o lugar da criação, portanto, da arte enquanto possibilidade de materializar através da atividade estética aquilo que experimentamos na vida; 


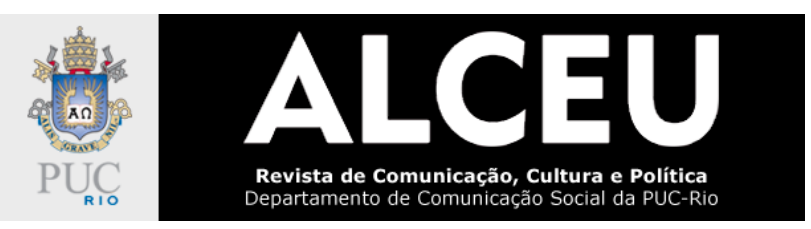

assim, neste tipo de pesquisa que se vale do uso de imagens técnicas, os participantes não apenas estão presentes no momento da atividade de campo, como também têm a possibilidade de emprestar um acabamento ao que viveram no processo da pesquisa, configurando uma prática que preza pela coautoria ao longo de todo o processo de produção do conhecimento.

Seguindo as pistas oferecidas pela reflexão de Benjamin, Bakhtin e Pasolini, saímos recompensados, detentores de um rico legado capaz de orientar outras formas de estar com o outro nas práticas de pesquisa, bem como de produzir conhecimento no campo das ciências humanas. O pesquisador mais consciencioso assume o compromisso ético e estético de aliar método e conhecimento, forma e conteúdo, a fim de que o seu olhar para as coisas do mundo lance luz sob aspectos importantes presentes em uma dada sociedade. Neste sentido, queremos construir uma educação estética do olhar para ampliar a discussão acadêmica, pois a imagem técnica produzida na academia pode auxiliar na construção de outra relação do sujeito com a imagem no mundo contemporâneo.

Por fim, podemos considerar que as narrativas imagéticas podem fornecer excedentes de visão (BAKHTIN, 1992) à vida, pois apresentam por outros ângulos a realidade vivenciada, suas negociações, conflitos e tensões. A utilização da imagem técnica na pesquisa intenciona levar às últimas consequências essa potencialidade produtora de excedente de visão, ao trazer ao participante da pesquisa um olhar estrangeiro para si próprio e, aos espectadores, um olhar para si a partir do encontro com o estrangeiro. Se, para tanto, o objetivo da produção do conhecimento em ciências humanas é fazer pensar criticamente a vida, as narrativas imagéticas parecem oferecer uma densidade reflexiva de outra ordem, mais direta e orgânica, assim como apostava Pasolini.

\section{Danilo Marques da Silva Godinho}

UNIFIMES - Centro Universitário de Mineiros Doutor em Psicologia Clínica pela PUC-Rio ORCID: $h$ ttps://orcid.org/0000-0002-2444-2634 E-mail:danilomgodinho@gmail.com

Cíntia de Sousa Carvalho

UNIFIMES - Centro Universitário de Mineiros Doutora em Psicologia Clínica pela PUC-Rio ORCID: https://orcid.org/0000-0002-7215-5074 E-mail: psi.cintiacarvalho@gmail.com

Recebido em: 26 de março de 2020.

Aprovado em: 22 de abril de 2020. 


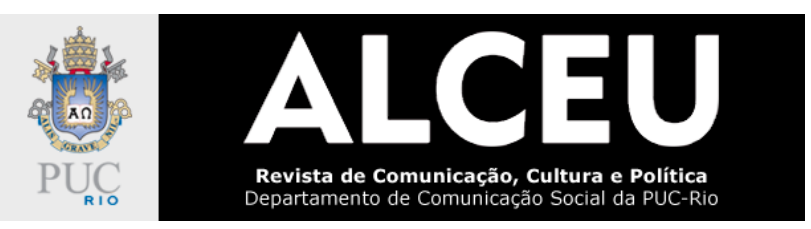

\section{Referências}

BAKHTIN, Mikhail. Estética da criação verbal. São Paulo: Martins Fontes, 1992.

BENJAMIN, Walter. Sobre a Linguagem em Geral e sobre a Linguagem Humana, tr. Maria Luz Moita, In: Sobre Arte, Técnica, Linguagem e Política. Lisboa: Relógio D’Água, 1992.

A obra de arte na era de sua reprodutibilidade técnica. In: Obras Escolhidas I: Magia e técnica, arte e política. São Paulo: Brasiliense, 1994.

FLUSSER, Vilém. O universo das imagens técnicas: Elogio da superficialidade. São Paulo: Annablume, 2008.

JOBIM e SOUZA, Solange. Imagem técnica e estética: Sobre os modos de produção da cultura e da subjetividade no mundo contemporâneo. In:

comunicação e cinema. Rio de Janeiro: Ed. PUC-Rio, 2008.

LAHUD, Michael. A vida clara. Linguagens e realidade segundo Pasolini. São Paulo: Companhia das Letras/Editora UNICAMP, 1993.

PASOLINI, Pier Paolo. Uma leitura dos signos de uma triste realidade. In: PASOLINI, P. P. Os jovens infelizes. Antologia dos ensaios corsários. São Paulo: Brasiliense, 1990.

SILVA, Adão Fernandes da. Pier Paolo Pasolini: O cinema como língua escrita da ação. Dissertação apresentada ao Curso de Mestrado da Escola de Belas Artes da Universidade Federal de Minas Gerais, 2007.

\section{Resumo}

O artigo aborda a presença das imagens técnicas na produção do conhecimento, problematizando o uso do recurso da videogravação em pesquisa acadêmica. Vale-se, para tanto, da articulação das reflexões acerca da linguagem desenvolvidas por Walter Benjamin (1892-1940) e Mikhail Bakhtin (1895-1975) à análise da produção teórica e cinematográfica de Pier Paolo Pasolini. Constata-se que o universo cinematográfico oferece subsídios para a utilização da imagem técnica na pesquisa em ciências humanas, ensejando a criação de narrativas imagéticas.

Palavras-chave: Pesquisa Acadêmica. Linguagem Cinematográfica. Imagens Técnicas. Narrativas Imagéticas.

\section{Abstract}

This article approach the presence of technical images in the production of knowledge, discussing the usage of video recording, in the academic research. It takes into consideration the reflection articulation about the language, developed by Walter Benjamin (1892-1940) and Mikhail Bakhtin $(1895-1975)$ to the analysis of the theoretical and movies production by Pier Paolo Pasolini. It is noted that the movies universe offers subsidies to the utilization of technical image in the human sciences research, making a way to the creation of imagery narratives.

Keywords: Academic Research. Movies Language. Technical Images. Imagery narratives. 


\section{Resumen}

El artículo aborda la presencia de imágenes técnicas en la producción de conocimiento, problematizando el uso de la grabación de video en la investigación académica. Para este propósito, la articulación de las reflexiones sobre el lenguaje desarrolladas por Walter Benjamin (1892-1940) y Mikhail Bakhtin (1895-1975) hace uso del análisis de la producción teórica y cinematográfica de Pier Paolo Pasolini. Parece que el universo cinematográfico ofrece subsidios para el uso de la imagen técnica en la investigación en ciencias humanas, dando lugar a la creación de narrativas de imágenes.

Palabras clave: Investigación Académica. Lenguaje Cinematográfico. Imágenes Técnicas. Narrativas de imágenes. 